$$
\begin{aligned}
& \text { كزارش شاهى ويرجينيايى (تيره كلميان) از فلور ايران }
\end{aligned}
$$

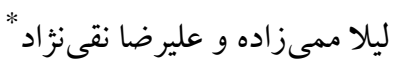

$$
\begin{aligned}
& \text { دريافت: | | } \\
& \text { كروه زيست شناسى، دانشكده علوم بايه، دانشگاه مازندران، بابلسر، ايران }
\end{aligned}
$$

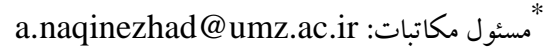

$$
\begin{aligned}
& \text { جكيده. در طول مطالعات فلوريستيك و يوشش گياهى در بخشهاى مختلف منطقه هير كانى (خزرى) شمال ايران، گونه Lepidium virginicum (تيره }
\end{aligned}
$$

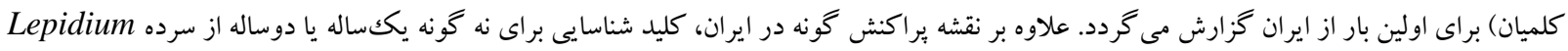

$$
\begin{aligned}
& \text { از ايران ارائه مى گردد. } \\
& \text { وازههاى كليدى. آسيا، حليّيائيان، گياه بيكانه، مازندران، مناطق شهرى }
\end{aligned}
$$

\title{
Lepidium virginicum L. (Brassicaceae), a new record for the flora of Iran
}

\author{
Leila Mamizadeh \& Alireza Naqinezhad* \\ Received: 12.11.2017 / Revised: 30.11.2017 / Accepted: 08.01.2018 / Published:21.12.2018
}

Department of Biology, Faculty of Basic Sciences, University of Mazandaran, Babolsar, Iran

*Corresponding author: a.naqinezhad@umz.ac.ir

\begin{abstract}
In the framework of floristic and vegetation studies of different parts of the Hyrcanian region of northern Iran, Lepidium virginicum L. (Brassicaceae) is reported here for the first time for the flora of Iran. Along with a distribution map for the species, an identification key is provided for the nine annual or biennial species of Lepidium, already reported from Iran.
\end{abstract}

Keywords. alien plant, Asia, Cruciferae, urban areas, Mazandaran

\section{INTRODUCTION}

Lepidium is one of the largest genera of the Brassicaceae consisting of about 260 species distributed worldwide, except Antarctica. It is regarded as one of the most natural genera in the family due to having angustiseptate fruits and simple trichomes when they are present (AlShehbaz, 2017).

According to Hedge (1968), six annual species of Lepidium are reported from Flora Iranica area $(L$. aucheri Boiss., L. sativum L., L. vesicarium L., L. perfoliatum L., $L$. pinnatifidum Ledeb. and $L$. ruderale L.). L. campestre (L.) R.Br. is added from Arasbaran protected area (Assadi, 1983). Moreover, two species from the genus Coronopus were moved to Lepidium as L. squamatum Forssk. and $L$. didymium L. (Al-Shehbaz, 2004; Fakhr Ranjbari,
2017). Therfore, total number of annual Lepidium species occurring in territory of Iran reaches eigth.

Two populations of Lepidium virginicum were collected in the urban areas of Babolsar, Mazandaran Province during a floristic and phytosociological investigation in the lowland and submontane Hyrcanian region. The species is hereby reported for the first time for Iran.

\section{MATERIALS AND METHODS}

Fieldwork was carried out in May-August 2017. The morphological features of the species were noted from the plant material collected during the field studies. The specimens were identified using botanical literatures of Iran and other areas (Boissier, 1867; Bush, 1939; Hedge, 1965, 1968; 
Jafri, 1973; Al-Shehbaz, 1986; De Carvalho e Vasconcellos et al., 1993; Zhou et al., 2001; AlShehbaz \& Gaskin, 2010; Fakhr Ranjbari, 2017). All characters of the specimens were surveyed by means of a stereomicroscope (Zeiss Stemi 2000-C). Digital herbaria of Vienna (W), Edinburugh (E), Kew (K), Berlin (B) and Natural History Museum of Paris (P) were carefully assessed. The materials recorded here were deposited in HUMZ.

\section{RESULTS AND DISCUSSION}

Lepidium virginicum L. in Sp. PI. 645 (1753). (Figs. 1-3).

Synonym: L. iberis L. in Sp. PI. 645 (1753).

Type: Herbarium Linneaus No. 824.18 (lectotype designated by Marais).

Mazandaran Province, Babolsar, on the road of Babolsar to Babol, Imam Khomeini str., 36 41' $18.05^{\prime \prime} \mathrm{N} ; 52^{\circ} 39^{\prime} 02.55^{\prime \prime} \mathrm{E},-22 \mathrm{~m}$ a.s.l., 29 June 2017, L. Mamizadeh 8050-HUMZ.

\section{Description}

Annual herb, 15-40 cm long. Stems usually simple from base, erect, branched above, puberulent with antrorse/retrorse, sub-appressed indumentums, 0.07-0.2 $\mathrm{mm}$ long, deciduous in elder materials. Basal leaves not-rosetted, early-deciduous, obovate or spathulate. Cauline leaves shortly petiolate; leaf blade oblanceolate or linear, $1-3 \mathrm{~cm} \times 2-5 \mathrm{~mm}$, attenuate or subcuneate toward base, leaf margin entire to serrate, not lobed, antrose puberulent along margins and midrib and rarely elsewhere. Inflorescence much elongated, with rather dense erect to ascending flowers; rachis and pedicels are puberulent with tiny curved, antrorse/retrorse, cylindric sub-appressed indumentums. Fruiting pedicels slender, spreading, $2.7-4.2 \mathrm{~mm} \times 0.3 \mathrm{~mm}$, glabrous abaxially. Sepals oblong to ovate, ca. $0.8 \times$ $0.5 \mathrm{~mm}$. Petals white, spatulate to oblanceolate, attenuate at base, $1 \times 0.3-0.4 \mathrm{~mm}$, rounded at apex. Stamens 2; filaments 0.8-1 mm long; anthers ca. 0.2 $\mathrm{mm}$ long. Fruit orbicular, glabrous, $2.5-3 \mathrm{~mm}$ in diam., narrowly winged apically, apex emarginate; apical notch ca. 0.3-0.5 mm long; width of the lower part of apical notch 0.2-0.3 mm long; style ca. 0.15-0.2 mm long, included in apical notch. Seeds reddish brown, ovate-oblong, narrowly winged, $1.5 \times 0.9-1 \mathrm{~mm}$, seed wing in the basal part 0.3-0.4 mm width.

\section{Taxonomic remarks}

Lepidium virginicum is closely related and frequently misidentified with $L$. ruderale, but differs from the latter by having petals, orbicular fruit and lyrate basal leaves (Table 1; Figs. 3). It also differs from $L$. pinnatifidum by having smaller style and glabrous fruits. Seeds are reddish brown and winged in L. virginicum vs. dullish yellow and wingless in $L$. pinnatifidum and $L$. ruderale. $L$. virginicum is classified in sect. Dileptium DC. This section is characterized by mostly winged fruit, free style, not amplexicaule leaves, 2-4 stamens. Based on a morphometric analysis of some species of this section, quantitative characters of density of the pedicels, length of stem hair, width of the silicle, width of the lower part of the apical noth, length of the beak and width of the wing in the basal part of the seed are regarded as diagnostic characters to distinguish $L$. virginicum from the most closely related species (Wąsowicz \& Rostański, 2009).

Table 1. Comparison between Lepidium virginicum and its most similar species.

\begin{tabular}{|l|l|l|l|}
\hline \multicolumn{1}{|c|}{ Characters } & \multicolumn{1}{|c|}{ L. virginicum } & \multicolumn{1}{c|}{ L. ruderale } & \multicolumn{1}{c|}{ L. pinnatifidum } \\
\hline Leaves & lower leaves lyrate & lower leaves bipinnate & basal leaves pinnatifid \\
\hline Petals & present, white, obovate-spatulate & absent & rudimentary (sometimes absent) \\
\hline Fruit & $\begin{array}{l}\text { orbicular, winged at apex, apical } \\
\text { notch 0.2-0.5 mm }\end{array}$ & $\begin{array}{l}\text { orbicular-elliptic, winged } \\
\text { at apex, apical notch 0.1- } \\
0.2 \mathrm{~mm}\end{array}$ & $\begin{array}{l}\text { elliptic-oval to sub-orbicular, } \\
\text { wingless, hardly emarginated }\end{array}$ \\
\hline Style & $\begin{array}{l}0.1-0.2 \mathrm{~mm}, \text { included in apical } \\
\text { notch. }\end{array}$ & $\begin{array}{l}\text { obsolete (or 0.1 mm, } \\
\text { included in apical notch) }\end{array}$ & as long as notch or longer \\
\hline Seed & reddish brown, winged & dark yellow, wingless & $\begin{array}{l}\text { dark yellow or dark rufous, } \\
\text { wingless }\end{array}$ \\
\hline
\end{tabular}




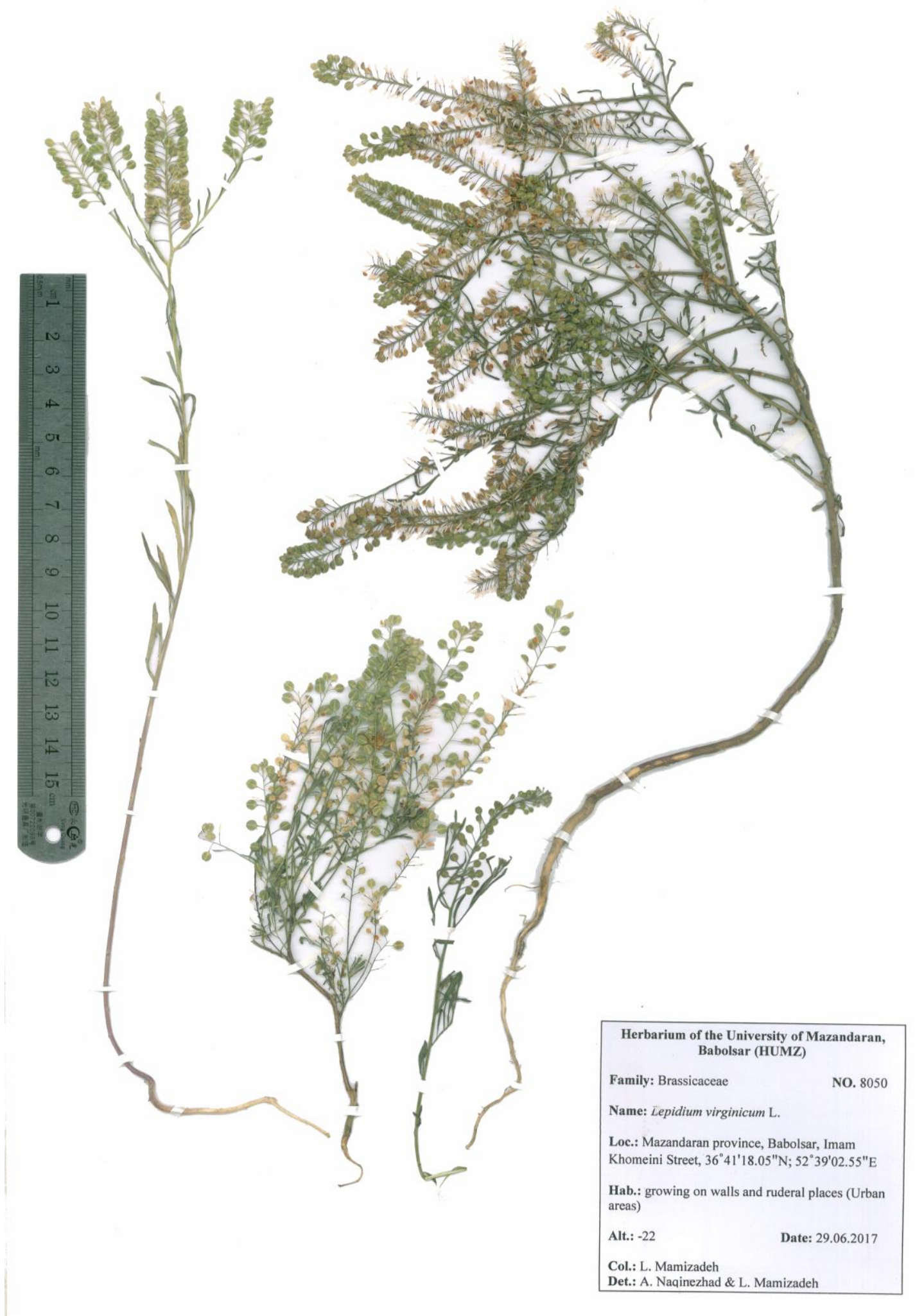

Fig. 1. Lepidium virginicum.

\section{Distribution and habitat}

Lepidium virginicum grows on the urban biotopes of the coastal city of Babolsar. The most important accompanying species included Artemisia annua L., Conyza bonariensis (L.) Cronquist, Coronopus didymus (L.) Sm., Cynodon dactylon (L.) Pers., Heliotropium europaeum L., Lophochloa phleoides (Vill.) Rchb., Oxalis corniculata L. and Sonchus oleraceus (L.) L. 
Lepidium virginicum is native to $\mathrm{N}$ America and has been introduced and widely naturalized elsewhere (De Carvalho e Vasconcellos et al., 1993; Zhou et al., 2001). In Europe, this is one of the most widespread alien plants occurring in more than $80 \%$ of all European countries (Pyšek et al., 2009). The distribution of the species is still expanding (e.g. Protopopova et al., 1994; Ilyinska,
2014; Stoyanov \& Vladimirov, 2015). The nearest recorded localities of the plant to Iran are NE Turkey (Davis et al., 1988) and Pakistan (Jafri, 1973).

Phenology. Flowering and fruiting from May to July.

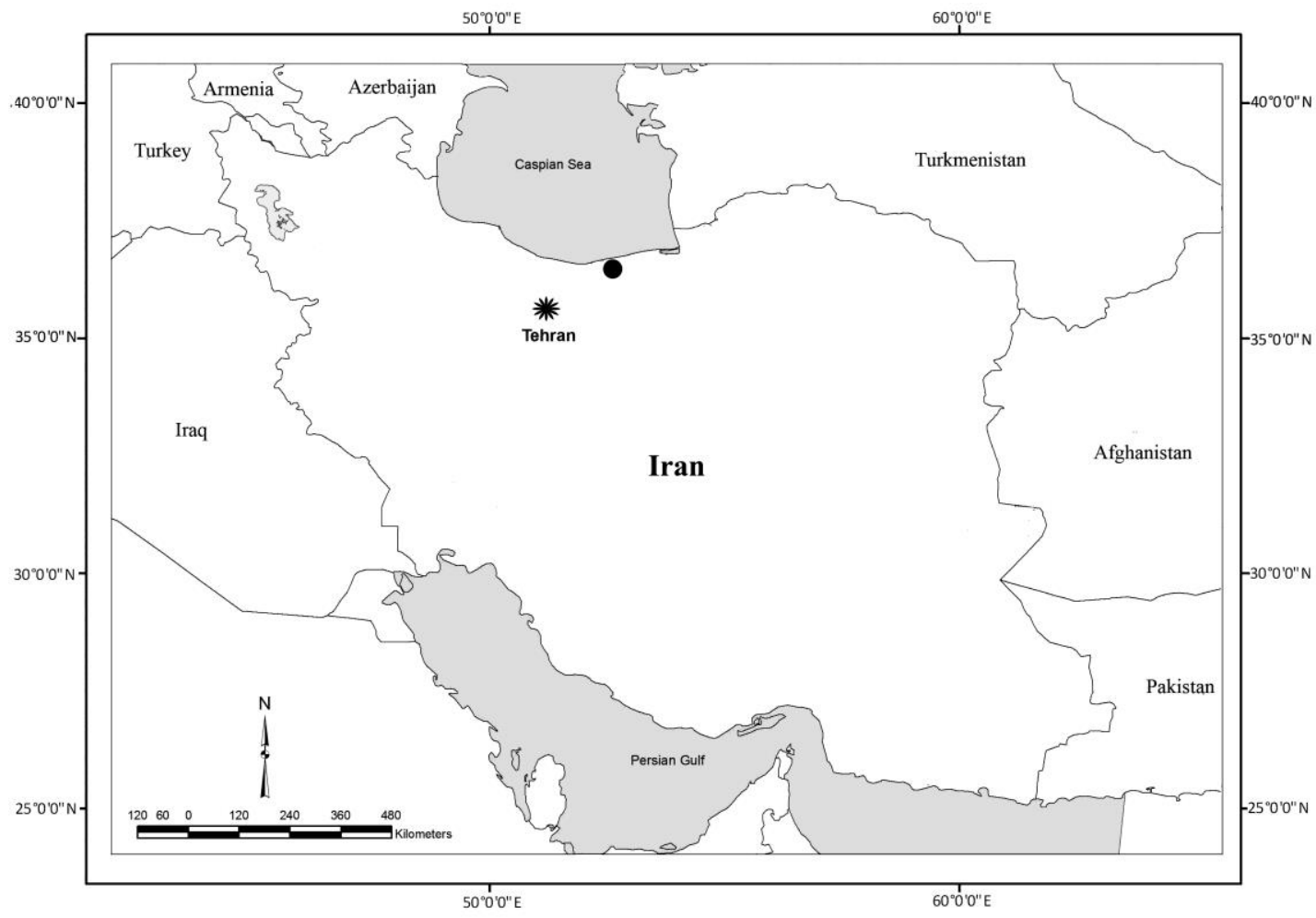

Fig. 2. Distribution map of Lepidium virginicum in Iran (•).

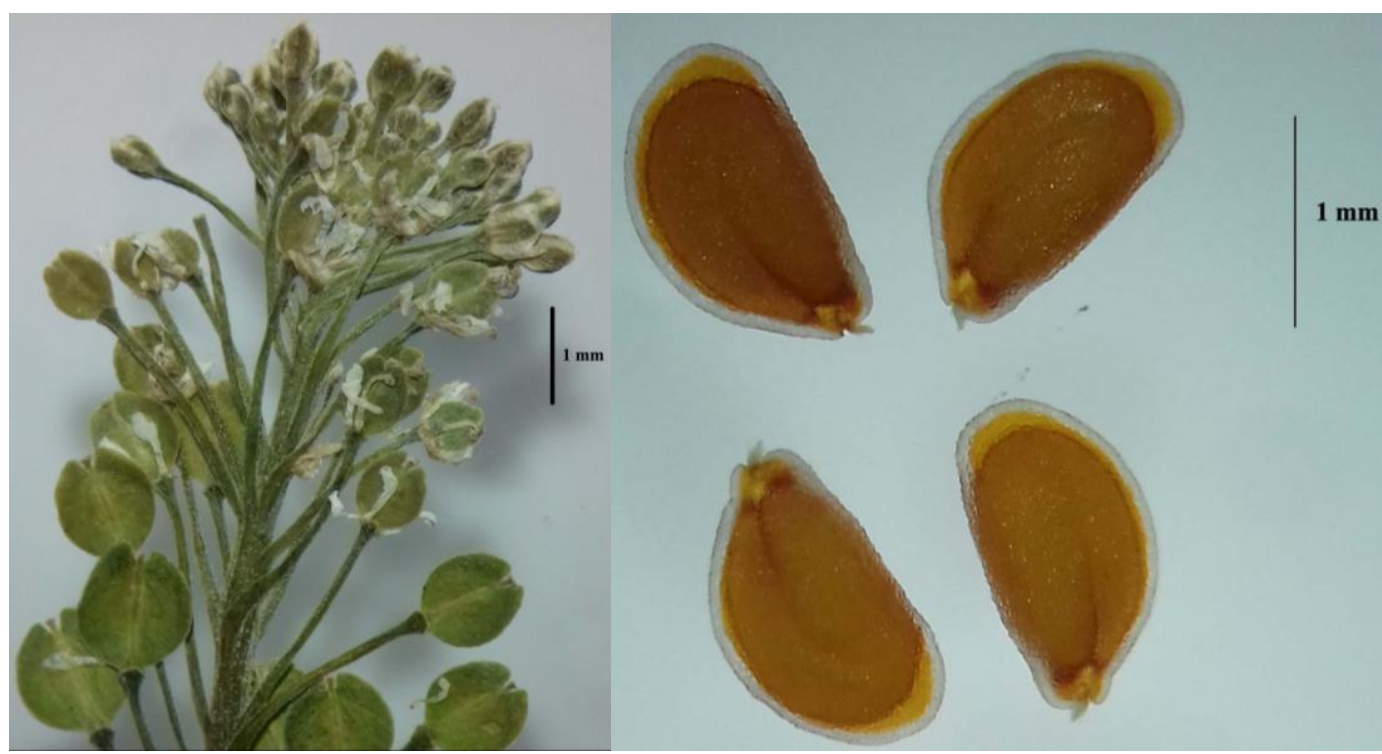

Fig. 3. Inflorescence (left) and seeds (right) of Lepidium virginicum. 


\section{Determination key for annual/biennial Lepidium species of Iran}

1-Fruits distinctly costate.

1-Fruits without distinct veins .L. squamatum

2-Fertile stamens 6 . L. didymum

2- Fertile stamens 2

4

3- Fruiting pedicels adpressed.

3- Fruiting pedicels spreading.....................5

4- Fruits 2.5-3 mm long, cotyledons entire..L. aucheri 4- Fruits 5-6 mm long, cotyledons trifid..L. sativum 5-Stems with prominent turbinate swellings at nodes.............................. vesicarium

5 -Stems not as above............................6

6-Cauline leaves amplexicaule.....................

6-Cauline leaves non amplexicaule..................8

7- Cauline leaves ovate-orbicular, flowers yellow... L. perfoliatum

7- Cauline leaves oblong-lanceolate, flowers white L. campestre

8- Fruits ovate, petals absent L. ruderale 8- Fruits orbicular, petals present.......L. virginicum

\section{ACKNOWLEDGEMENT}

The research has been supported by the Center for International Scientific Studies and Collaboration (CISSC), Iran. We also thank University of Mazandaran for providing facilities for doing this research under a research grant (Grant No. $22531 / 33 / 95$ ) to the second author.

\section{REFERENCES}

Al-Shehbaz, I.A. 2017. Five new species of Lepidium (Brassicaceae): L. pabotii (Iran), L. arequipa (Peru), L. lapazianum, L. linearilobum, and L. stephan-beckii (Bolivia). - Novon 25: 403-413.

Al-Shehbaz I.A. and Gaskin J.F. 2010. Lepidium L. In: Flora of North America North of Mexico (eds FNA Editorial Committee), vol 7. - New York \& Oxford, Oxford Univ. Press. http://www.efloras.org/.

Al-Shehbaz, I.A. 2004. Novelties and notes on miscellaneous Asian Brassicaceae. - Novon 14: 153157.

Al-Shehbaz, I.A. 1986. The genera of Lepidieae (Cruciferae; Brassicaceae) in the southeastern United States. - J. Arnold Arbor. 67: 265-311.

Assadi, M. 1983. Plants from N. Azarbayejan, new to Iran. - Iran. J. Bot. 2(1): 1-8.

Boissier, E. 1867. Flora Orientalis, Vol. 1. - Georg, Geneva \& Basilea, Basel.

Bush, N.A. 1939. Lepidium L. - In: Bush, N.A. (ed), Flora of USSR. vol. 8: 501-524. - Akademii Nauk SSSR, Leningrad.
Davis P.H., Mill R.R. and Tan K. 1988. Flora of Turkey and the East Eagean Islands. Vol. 10. Edinburgh University Press, Edinburgh.

De Carvalho e Vasconcellos J., Akeroyd, J. R. and Rich, T.C.G. 1993. Lepidium L. - In: Flora Europaea (eds Tutin, T.G., Burges, N.A., Chater, A.O., Edmondson, J.R., Heywood, V.H., Moore, D.M., Valentine, D.H., Walters, S.M., Webb, D.A.) 1: 398402. - Cambridge University Press, Cambridge.

Fakhr Ranjbari, H. 2017. Lepidium. - In: Assadi, M., Maassoumi, A. and Sajedi, S. (eds.), Flora of Iran no. 143 (Brassicaceae). pp. 102-137. - RIFR. Tehran.

Hedge, I. 1968. Lepidium L. - In: Rechinger, K.H. (ed), Flora Iranica vol. 57: 63-72. - Akad. Druck-und Verlagsanstalt, Graz.

Hedge, I. 1965. Lepidium L. - In: Davis, P.H. (ed). Flora of Turkey and the East Aegean Islands 1: 279-285. Edinburgh University Press, Edinburgh.

Ilyinska, A.P. 2014. Lepidium s. str. (Brassicaceae) in the flora of Ukraine. Biodiversity Research and Conservation 35: 25-29.

Jafri, 1973. Lepidium L. - In: in Nasir, E. \& Ali, S. I (ed.), Fl. W. Pakistan. 55: 60.

Protopopova V.V., Mosyakin S.L. and Shevera M.V. 1994. Lepidium virginicum L., new species in Ukrainian flora. - Ukr. Botan. Journ. 51: 225-228.

Pyšek, P., Lambdon, Ph.W., Arianoutsou, M., Kühn, I., Pino, J. and Winter, M. 2009. Chapter 4. Alien vascular plants of Europe. In: Handbook of alien species in Europe, Springer Science + Busines Media B. V. 43-61.

Stoyanov, S., and Vladimirov, V. 2015. Lepidium virginicum (Brassicaceae)-a new non-native species to the Bulgarian flora. - Compt. Rend. Acad. Bulg. Sci. 68: 725-728.

Wąsowicz, P. and Rostański, A. 2009. The use of quantitative characters in determination of frequently misdiagnosed species within Lepidium L. sect. Dileptium (Brassicaceae). Acta Soc. Bot. Pol. 78: 221-227.

Zhou, T.Y., Lu L.L., Yang G and Al-Shehbaz, I.A. 2001. Brassicaceae (Cruciferae). - In: Wu, Z.-G. \& Raven, P.H. (eds.), Flora of China (Brassicaceae through Saxifragaceae). vol. 8:1-193. - Science Press, Beijing, and Missouri Botanical Garden Press, St. Louis.

$$
* * * * *
$$

How to cite this article:

Mamizadeh, L. and Naqinezhad, A. 2018. Lepidium virginicum (Brassicaceae), a new record for the flora of Iran. - Nova Biol. Reperta 5 (3): 324-328. 